\title{
A Comparative Study of Teaching Process of Presenting Product Sketch Design of Industrial Design Program
}

\author{
Pracha Pijukkana ${ }^{1} \&$ Yanin Rugwongwan ${ }^{1}$ \\ ${ }^{1}$ Faculty of Architecture, King Mongkut's Institute of Technology Ladkrabang (KMITL), Bangkok, Thailand \\ Correspondence: Pracha Pijukkan. Tel: 668-1403-7546. E-mail: ton_pracha@hotmail.co.th
}

Received: October 11, 2017

Accepted: October 30, 2017

Online Published: November 28, 2017

doi:10.5539/ass.v13n12p174

URL: https://doi.org/10.5539/ass.v13n12p174

\begin{abstract}
This research studies the teaching process of idea communication for industrial product design sketching. The objective of this research is to make a comparative study on the efficiency of two teaching processes between teaching with detailed information and teaching with conceptual frameworks for groups of students who have different learning aptitudes; which are an aptitude in theoretical subjects or an aptitude in practical subjects. The study also included differences in learning styles of the industrial design program undergraduate students. The researchers came up with an experiment of creating sketch design ideas for a product in which the researchers classified the students' learning processes from curriculum subjects and academic achievements. The results found that curriculum subjects and students' learning aptitude can be grouped into two major groups: students who have accumulated scores in theoretical subjects and students who have accumulated scores in practical subjects. These two groups of students have different aptitudes in sketch design idea communication processes: a process of sketching with given detailed information and a process of sketching with given conceptual framework. Although these are different processes, the teaching and learning of these two product design processes have the same objectives: to create design ideas and to support design creativity by using the concept of interaction between the brain, hands and shapes that appear on paper to present the sketch product and to guide the teaching and learning of industrial product design, suitable for students who have different characteristics and help increase their academic achievements.
\end{abstract}

Keywords: teaching process, sketch design, industrial design

\section{Introduction}

The teaching and learning of product design will develop the knowledge and skills of the students making creative designs. This requires integration of knowledge in science, technology and art by emphasizing creativity and the development of design concepts related to differences in outward appearance and with consideration for function, value, and appearance of the product, including form and size (Soodsang, 2005); in this way it is possible to create products that will maximize the benefit for both consumers and manufacturers. Sahachaisaeree (2004) states that designers usually work with forms and shapes. Though designers usually apply the "Elements of Design" and "Principles of Design" when creating a product, the experts will also apply strategies and skills which they have accumulated through interaction between brain, hands and shapes that appear on paper. (Laseau, 2001) calls this process "Graphic thinking" which is consistent with the Design development spiral of Zeisel. The process of Graphic thinking begins with the images that appear in the brain and are transferred via the hand onto paper; the brain then interacts with these basic ideas on paper through the eyes to further analyze and adjust; then the brain will apply more changes through the hand onto the paper. These processes will happen again and again until the designs are completed The characteristics of the Design development spiral is that after completing the basic designs, the designers will alter the original ideas and develop them into the most suitable one (Sahachaisaeree, 2004; Zeisel, 1981). Thus, developing design skills is very important for analyzing products and developing creative idea solutions (Authority, 2013). In addition, conceptual design is an important element and factor that generates design creativity, new styles and uniqueness of products. Also, a systematical design concept will enable the designer to create products that follow the procedures of the teaching-learning process of product design and allows them to create products effectively.

Therefore, the teaching-learning process of product design must include practice drawing product sketches in order to present design ideas. Untrained students with different learning skills have to rely on techniques and an appropriate teaching process to be successful in their studies. In general, learning from experience (Experiential Learning Cycle Theory), Kolb (1984) explains that each student learns something new from experience which intends to encourage the student to use his/her acquired knowledge and to increase this knowledge and the ability to use the design skills; this can be done by providing the opportunity for students to have concrete experiences. The industrial design classes have teaching techniques that are different from other classes because it has a curriculum comprising both theoretical lectures and practical training for Design Projects. Students can find their own learning principles by making mistakes; as a result, each student would have different learning processes, perception and behaviours. In the past, teaching techniques usually were based on a teacher-centred approach, which is a technique in which the teacher organizes and 
conducts most of the teaching activities. In other word, teachers would use the technique that they are familiar with and students would have a very little role in participating in activities. Therefore, the teacher-centred approach is more like a one-way communication which does not focus on different learning abilities of the students. This research aims to study the Design Idea Communication Process comparing teaching using detailed information and teaching using conceptual frameworks techniques. This research will focus on the different learning styles and techniques for industrial design students in order to classify these techniques from the curriculum subjects and the academic achievements of the students and to do a comparative study on different teaching processes for presenting product sketches. This is an interesting subject because if we understand the learning behavior of students in each group, we will be able to provide teaching-learning techniques that are suitable for the learning ability of students in each group. As a result, this could help increasing the academic achievement of students.

\section{Research Conceptual Framework}

Based on the introduction of a comparative study of teaching processes to present product sketch designs in the industrial design program, the researchers came up with a conceptual framework as a guide, see Figure 1.

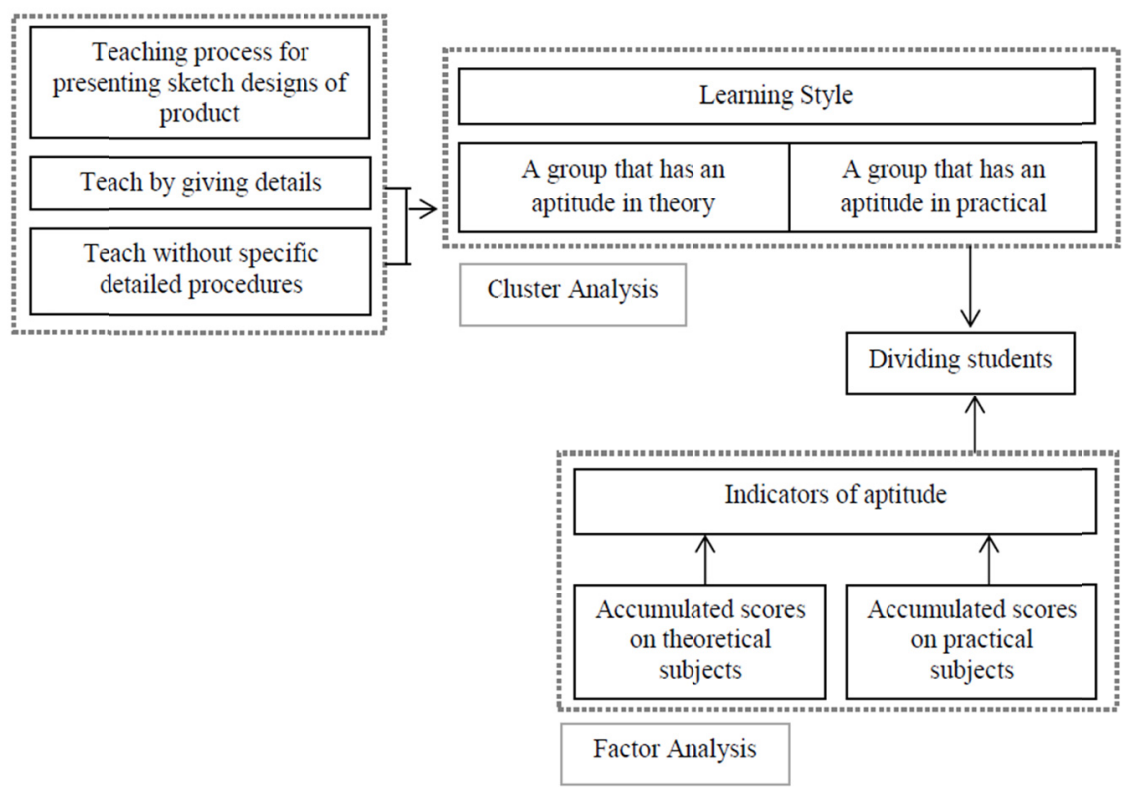

Figure 1. Conceptual framework

\section{Method}

In this research sample groups were selected by a non-probability sampling method; the members were all undergraduate students of the industrial design program at Rajamangala University of Technology, Phra Nakhon, Thailand. The researchers have conducted a comparative study of teaching processes to present product sketch design in the industrial design program in order to develop a set of indicators for evaluation and to create testing tools to evaluate the teaching-learning process of the industrial design program. The data collection method was divided into six steps as follows.

3.1 Step 1 - We studied and collected transcript data of 4 classes of undergraduate students of the industrial design program. Three of these classes are now graduate students (totaling 124 students); the fourth class includes this year's students (totaling 65 students).

3.2 Step 2 - The researches then proceeded reviewing students' grades in each subject to find the correlation of all variable pairs and a relationship between academic performance and courses taken in the curriculum.

3.3 Step 3 - After calculating the correlation coefficients for each pair of variables in Step 2, in this step the factorial analysis method was used to divide the variable subjects into group variables to determine the groups of aptitude indicators. The study found two groups of aptitude indicators: a group with accumulated scores in theoretical subjects and a group with accumulated scores in practical subjects.

3.4 Step 4 - Data was used from grade point performance of 65 students who are currently in their last year complying with the factor analysis, to divide students into groups by using cluster analysis in order to do an exploratory factor analysis of aptitude indicators groups. This yielded groups of variables in which variables in the same group are more related than variables from different groups; while variables from different group are less related or are not related at all.

3.5 Step 5 - We conducted a test asking students to draw a sketch design. The test was divided into two sessions of 8 hours each. The first test session (Sketch Design 1) explained the steps and scoring criteria in full detail, while the 
second test session (Sketch Design 2) did not provide detailed instruction and scoring criteria. Each test had a score of 100 points, the test details were as follows:

The first test session (Sketch Design 1) asked the students to draw sketch designs of a toaster onto A2 size paper following the process of design development; the scoring criteria are detailed in Table 1.

Table 1. Evaluation Procedures for Sketch Design Development

\begin{tabular}{lc}
\hline \multicolumn{1}{c}{ Evaluation Procedure } & Points \\
\hline Step 1 Problem Identification & 10 \\
- Problem Statement & 5 \\
- Troubleshooting & 5 \\
Step 2 Preliminary Ideas & 5 \\
Step 3 Design Refinement & 10 \\
Step 4 Analysis & 20 \\
- Function Analysis & 5 \\
- Engineering Analysis & 5 \\
- Specification Analysis & 5 \\
- Market and Product Analysis & 5 \\
Step 5 Decision & 20 \\
- Human Factors & 5 \\
- Strength & 5 \\
- Ergonomic & 5 \\
- Safety & 5 \\
Step 6 Implementation & 35 \\
- Design creativity & 10 \\
- Identification & 5 \\
- Aesthetic & 10 \\
- Element of Sketch Design & Total \\
\hline
\end{tabular}

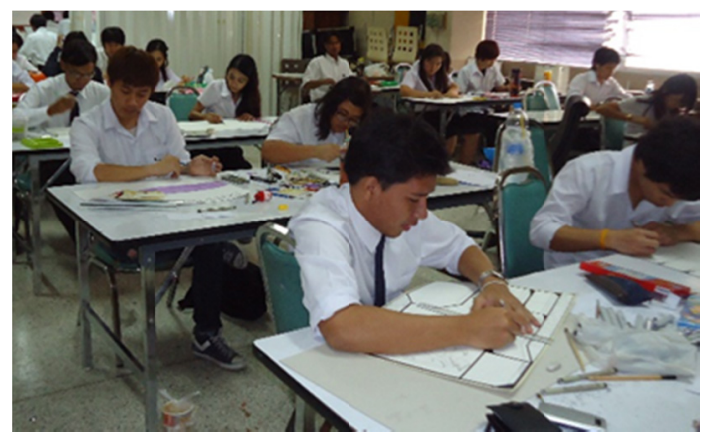

Figure 2. Test session 1, students are asked to draw sketches design of a given product

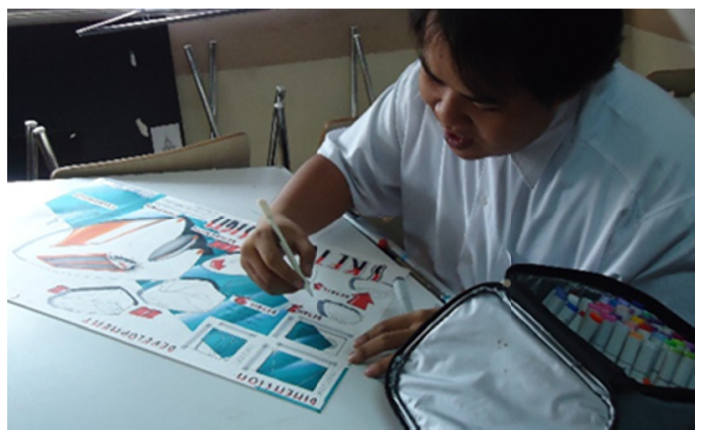

Figure 3. Test session 2, students are asked to draw sketches design based on story and scenario

Test session 2 (Sketch Design 2): Students were asked to draw sketch designs of a product according to a given story or case scenario instead of being given exact product type. There were no given detailed procedures and scoring criteria, the students had to do the product analysis by themselves. In this case, the students were asked to draw a sketch design of a product to support making breakfast in David's family. David and his family live in Thailand; there are four family members including David, an American businessman aged 42; he has to rush to get to work on time after driving his son to school every morning. His Thai wife, aged 38, stays home to take care of the family. They have a son, aged 10 and a 1-year-old daughter. The students had to come up with a product design suitable for this family, and draw it onto A2 size paper (100 points).

3.6 Step 6 - Students had to submit their designs from both tests to 30 experts and professors involved in teaching product design from different universities, to evaluate the quality of their sketch designs. Then, the experts and professors made a result analysis conclusion and combined this with the results of cluster group analyses to see the difference in results coming from factor analysis used to group the curriculum subjects into theoretical subjects and practical subjects. Then, the experts and professors divided the students into two groups based on their scores from both product sketching tests. The first group was the group of students having an aptitude in theoretical subjects and a group of students having an aptitude in practical subjects. After that, the experts and professors answered the questions about the objectives of the research, specifically about teaching and learning styles. 


\section{Results}

\subsection{Correlation Coefficient between grade performance and subjects}

From examining the academic performance of students in each subject, the relationship between the student's grade performance and the subjects are found by computing Pearson's correlation coefficient ( $r$ ) between each pair of subject variables and it shows a statistically significant relationship between each pair of variables, having a coefficient of correlation greater than 0.5 ; the details are shown in Table 2.

Table 2. Pearson Correlation Coefficient between grade performance and subjects.

\begin{tabular}{|c|c|c|}
\hline Subject & & \\
\hline \multirow{2}{*}{ History of Design } & Pearson Correlation & .549 \\
\hline & Sig. (2-tailed) & $.000 * *$ \\
\hline \multirow{2}{*}{ Composition of Art } & Pearson Correlation & .549 \\
\hline & Sig. (2-tailed) & $.000 * *$ \\
\hline \multirow{2}{*}{ Principles of Drafting } & Pearson Correlation & .507 \\
\hline & Sig. (2-tailed) & $.000 * *$ \\
\hline \multirow{2}{*}{ Drawing Techniques } & Pearson Correlation & .539 \\
\hline & Sig. (2-tailed) & $.000 * *$ \\
\hline \multirow{2}{*}{ Computer Technology } & Pearson Correlation & .592 \\
\hline & Sig. (2-tailed) & $.000 * *$ \\
\hline \multirow{2}{*}{ Principles of Design } & Pearson Correlation & .576 \\
\hline & Sig. (2-tailed) & $.000 * *$ \\
\hline \multirow{2}{*}{ Industrial Drafting } & Pearson Correlation & .500 \\
\hline & Sig. (2-tailed) & $.000 * *$ \\
\hline \multirow{2}{*}{ Painting Techniques } & Pearson Correlation & .572 \\
\hline & Sig. (2-tailed) & $.000 * *$ \\
\hline \multirow{2}{*}{ Ergonomics } & Pearson Correlation & .576 \\
\hline & Sig. (2-tailed) & $.000 * *$ \\
\hline \multirow{2}{*}{ Model Making } & Pearson Correlation & .592 \\
\hline & Sig. (2-tailed) & $.000 * *$ \\
\hline \multirow{2}{*}{ Workshop } & Pearson Correlation & .556 \\
\hline & Sig. (2-tailed) & $.000 * *$ \\
\hline \multirow{2}{*}{ Cost and Price Analysis } & Pearson Correlation & .548 \\
\hline & Sig. (2-tailed) & $.000 * *$ \\
\hline \multirow{2}{*}{ Industrial Product Design1 } & Pearson Correlation & .592 \\
\hline & Sig. (2-tailed) & $.000 * *$ \\
\hline \multirow{2}{*}{ Industrial Product Design2 } & Pearson Correlation & .556 \\
\hline & Sig. (2-tailed) & $.000 * *$ \\
\hline \multirow{2}{*}{ Industrial Product Design3 } & Pearson Correlation & .635 \\
\hline & Sig. (2-tailed) & $.000 * *$ \\
\hline \multirow{2}{*}{ Industrial Product Design4 } & Pearson Correlation & .567 \\
\hline & Sig. (2-tailed) & $.000 * *$ \\
\hline \multirow{2}{*}{ Industrial Product Design5 } & Pearson Correlation & .567 \\
\hline & Sig. (2-tailed) & $.000 * *$ \\
\hline \multirow{2}{*}{ Materials and Production } & Pearson Correlation & .518 \\
\hline & Sig. (2-tailed) & $.000 * *$ \\
\hline \multirow{2}{*}{ Computer Aided Design1 } & Pearson Correlation & .590 \\
\hline & Sig. (2-tailed) & $.000 * *$ \\
\hline \multirow{2}{*}{ Computer Aided Design2 } & Pearson Correlation & .508 \\
\hline & Sig. (2-tailed) & $.000 * *$ \\
\hline \multirow{2}{*}{ Seminar } & Pearson Correlation & .635 \\
\hline & Sig. (2-tailed) & $.000 * *$ \\
\hline \multirow{2}{*}{ Industrial Product Research } & Pearson Correlation & .590 \\
\hline & Sig. (2-tailed) & $.000 * *$ \\
\hline \multirow{2}{*}{ Ceramic Design } & Pearson Correlation & .538 \\
\hline & Sig. (2-tailed) & $.000 * *$ \\
\hline Crenhic Decion & Pearson Correlation & .500 \\
\hline Graphic Design & Sig. (2-tailed) & $.000 * *$ \\
\hline
\end{tabular}

**. Correlation is significant at the 0.01 level (2-tailed). 


\subsection{Factor analysis to determine the groups of aptitude indicators}

The subject variables are grouped by Factor Analysis method to find groups of aptitude indicator factors. By using the academic achievement of 4 classes of industrial design students which included 3 classes of already graduated students, and students who currently are in their last year of the program, it is found that the factor loading is medium; as a result, it is unable to find Factor Indicator Variable. Thus, the researchers use the Equamax Rotation instead and find 2 main factor groups of theoretical subjects; there are 10 subjects in this group as follows: History of Design, Composition of Art, Drawing Techniques, Principles of Design, Principles of Drafting, Ergonomics, Seminar in Industrial Product Design, Industrial Product Research and Development, Materials and Production and Cost and Price Analysis, subjects that focus on theoretical and basic design, and a group of practical study subjects; there are 14 subjects in this group as follows: Industrial Drafting, Painting Techniques, Industrial Product Design 1-5, Model Making, Workshop, Computer Technology, Computer Aided Design and Manufacturing 1-2, Ceramic Design and Graphic Design, subjects that more focus on practical study than theory; the details are shown in Table3.

Table 3. Grouping the variables subjects by using Factor Analysis method

\begin{tabular}{|c|c|c|}
\hline \multirow{2}{*}{ Subjects } & \multicolumn{2}{|c|}{ Aptitude indicator factors } \\
\hline & Theoretical subjects & Practical subjects \\
\hline History of Design & .742 & .252 \\
\hline Composition of Art & .757 & .096 \\
\hline Drawing Techniques & .603 & .417 \\
\hline Principles of Design & .706 & .130 \\
\hline Principles of Drafting & .572 & .338 \\
\hline Ergonomics & .572 & .303 \\
\hline Seminar in Industrial Product Design & .592 & .012 \\
\hline Industrial Product Research and Development & .606 & .165 \\
\hline Materials and Production & .577 & .225 \\
\hline Cost and Price Analysis & .582 & .180 \\
\hline Industrial Drafting & .143 & .542 \\
\hline Painting Techniques & .388 & .572 \\
\hline Industrial Product Design 1 & .158 & .597 \\
\hline Industrial Product Design 2 & .071 & .573 \\
\hline Industrial Product Design 3 & .052 & .535 \\
\hline Industrial Product Design 4 & .200 & .587 \\
\hline Industrial Product Design 5 & .270 & .796 \\
\hline Model Making & .296 & .581 \\
\hline Workshop & .136 & .618 \\
\hline Computer Technology & .266 & .547 \\
\hline Computer Aided Design and Manufacturing 1 & .331 & .565 \\
\hline Computer Aided Design and Manufacturing 2 & .124 & .517 \\
\hline Ceramic Design & .053 & .640 \\
\hline Graphic Design & .132 & .576 \\
\hline
\end{tabular}

\subsection{Exploratory factor analysis of students' aptitude}

The following displays statistics data used to group the students by using Cluster Analysis to find the aptitude indicator factors; using the academic achievement of 65 students of the last year industrial design program and this should be consistent with factor analysis. From the analysis, it is found that 30 students are put into one group due to their accumulated scores in theoretical subjects and 35 students are put into another group due to their accumulated scores in practical subjects; the details are shown in Table 4.

Table 4. Grouping students based on their aptitude by using Cluster Analysis

\begin{tabular}{|c|c|c|c|c|c|}
\hline \multirow{2}{*}{$\begin{array}{l}\text { Order of } \\
\text { students }\end{array}$} & \multicolumn{2}{|c|}{ Aptitude indicator factors } & \multirow{2}{*}{$\begin{array}{l}\text { Order of } \\
\text { students }\end{array}$} & \multicolumn{2}{|c|}{ Aptitude indicator factors } \\
\hline & Theoretical subjects & Practical subjects & & Theoretical subjects & Practical subjects \\
\hline 1 & 0.248671 & -0.54065 & 34 & 0.841689 & -0.27741 \\
\hline 2 & 0.205925 & 0.673306 & 35 & 0.128578 & 0.886047 \\
\hline 3 & 0.836422 & -1.02788 & 36 & 0.08967 & -1.70081 \\
\hline 4 & 0.609329 & 0.008269 & 37 & 1.22204 & -0.73975 \\
\hline 5 & 0.733625 & -0.33013 & 38 & 0.822663 & -2.41822 \\
\hline 6 & 0.657702 & 0.208207 & 39 & 0.025847 & -1.11792 \\
\hline
\end{tabular}




\begin{tabular}{rrrrrrr}
7 & 0.259478 & -1.79647 & 40 & -2.0085 & -2.85519 \\
8 & 0.857075 & -1.0805 & 41 & -1.84759 & -4.00937 \\
9 & 0.167104 & -0.84682 & 42 & 0.897067 & -3.07237 \\
10 & 0.380872 & -1.23023 & 43 & 0.635235 & -0.90404 \\
11 & 0.157809 & 0.239769 & 44 & -0.63329 & -0.15434 \\
12 & 0.325474 & -1.67175 & 45 & 0.751639 & 0.772339 \\
13 & 0.575998 & 0.116256 & 46 & 0.530648 & -1.18713 \\
14 & 0.515985 & 0.249676 & 47 & 1.160491 & -2.13405 \\
15 & -0.08353 & -0.16298 & 48 & 0.857994 & 0.513377 \\
16 & 0.250531 & 0.222453 & 49 & 1.089357 & -0.76911 \\
17 & 0.634965 & 0.822956 & 50 & -0.27865 & -3.65483 \\
18 & 1.157 & -0.27819 & 51 & -0.00273 & -4.04598 \\
19 & 1.191205 & -1.14112 & 52 & 1.454544 & 0.660642 \\
20 & 0.918297 & 0.473976 & 53 & 0.801982 & 0.918156 \\
21 & 0.640038 & -0.46795 & 54 & 1.004072 & -0.61672 \\
22 & 0.510861 & -0.40358 & 55 & 0.735356 & -0.63871 \\
23 & 0.420357 & -0.90734 & 56 & -0.49732 & 0.205021 \\
24 & -1.8415 & -1.2389 & 57 & 0.627335 & 0.164044 \\
25 & 0.493202 & -2.08729 & 58 & 1.422865 & -0.65842 \\
26 & 0.343656 & -1.00818 & 59 & -0.18303 & -1.64284 \\
27 & 1.095256 & -1.25661 & 60 & 0.874389 & 0.74303 \\
28 & 1.096936 & -0.3077 & 61 & 0.857588 & 0.728852 \\
29 & 0.257146 & -1.34767 & 62 & 0.212006 & -2.9305 \\
30 & -0.21077 & 1.029677 & 63 & 0.177405 & 0.349769 \\
31 & 0.565304 & 0.630503 & 64 & 0.784662 & 1.671325 \\
32 & 1.179343 & 0.431152 & 65 & 1.048526 & -1.15582 \\
33 & 0.776685 & 1.316716 & Total & 30 Students & 35 Students \\
\hline
\end{tabular}

Table 5. The average score and the comparison between Sketch Design 1 and Sketch Design 2

\begin{tabular}{|c|c|c|c|c|c|c|c|c|c|}
\hline \multirow[t]{2}{*}{$\begin{array}{l}\text { Order of } \\
\text { students }\end{array}$} & \multirow{2}{*}{$\begin{array}{c}\text { Sketch } \\
\text { Design } 1\end{array}$} & \multirow{2}{*}{$\begin{array}{c}\text { Sketch } \\
\text { Design } 2\end{array}$} & \multicolumn{2}{|c|}{$\begin{array}{l}\text { Paired Samples } \\
\text { Test }\end{array}$} & \multirow[t]{2}{*}{$\begin{array}{l}\text { Order of } \\
\text { students }\end{array}$} & \multirow{2}{*}{$\begin{array}{c}\begin{array}{c}\text { Sketch } \\
\text { Design } 1\end{array} \\
M(S D)\end{array}$} & \multirow{2}{*}{$\begin{array}{c}\begin{array}{c}\text { Sketch } \\
\text { Design } 2\end{array} \\
M(S D)\end{array}$} & \multicolumn{2}{|c|}{$\begin{array}{l}\text { Paired Samples } \\
\text { Test }\end{array}$} \\
\hline & & & $\mathrm{t}$ & $p$ & & & & $\mathrm{t}$ & $p$ \\
\hline 4 & $75.33(5.16)$ & $67.00(6.51)$ & 2.90 & $0.034 *$ & 1 & $68.33(3.93)$ & $60.00(4.34)$ & 4.18 & $0.009 *$ \\
\hline 5 & $73.50(7.71)$ & $64.50(5.89)$ & 5.14 & $0.004 *$ & 2 & $64.67(1.51)$ & $74.67(6.86)$ & -4.33 & $0.007^{*}$ \\
\hline 6 & $73.33(2.07)$ & $66.50(5.99)$ & 3.52 & $0.017 *$ & 3 & $62.33(6.74)$ & $70.67(5.20)$ & -4.21 & $0.008^{*}$ \\
\hline 13 & $77.17(4.53)$ & $72.17(2.48)$ & 3.73 & $0.014^{*}$ & 7 & $69.00(8.99)$ & $66.33(12.7)$ & 1.13 & 0.310 \\
\hline 14 & $69.67(8.57)$ & $66.33(8.09)$ & 4. 15 & $0.009 *$ & 8 & $70.50(6.38)$ & $78.83(4.36)$ & -5.93 & $0.002 *$ \\
\hline 16 & $72.00(5.25)$ & $64.33(6.50)$ & 7.75 & $0.001 *$ & 9 & $65.33(5.81)$ & $72.17(4.31)$ & -6.01 & $0.002 *$ \\
\hline 18 & $73.83(4.26)$ & $66.50(6.53)$ & 5.50 & $0.003^{*}$ & 10 & $62.00(5.37)$ & $70.83(8.11)$ & -5.32 & $0.003 *$ \\
\hline 19 & $68.00(4.43)$ & $60.84(6.37)$ & 8.22 & $0.000 *$ & 11 & $63.83(7.83)$ & $73.00(6.13)$ & -4.95 & $0.004 *$ \\
\hline 20 & $68.33(2.42)$ & $73.17(3.55)$ & -8.04 & $0.000 *$ & 12 & $66.83(5.27)$ & $74.17(5.63)$ & -5.31 & $0.003 *$ \\
\hline 21 & $75.33(3.44)$ & $69.67(4.84)$ & 6.17 & $0.002 *$ & 15 & $68.00(3.35)$ & $75.33(6.98)$ & -3.68 & $0.014 *$ \\
\hline 22 & $73.00(2.83)$ & $68.17(3.55)$ & 6.45 & $0.001 *$ & 17 & $74.33(8.96)$ & $71.50(8.78)$ & 0.94 & 0.392 \\
\hline 24 & $74.17(3.25)$ & $78.50(3.27)$ & -7.77 & $0.001 *$ & 23 & $68.67(4.03)$ & $73.67(2.94)$ & -7.32 & $0.001^{*}$ \\
\hline 28 & $86.17(4.07)$ & $81.33(3.39)$ & 5.80 & $0.002 *$ & 25 & $62.50(3.02)$ & $66.83(3.06)$ & -6.06 & $0.002 *$ \\
\hline 32 & $74.50(4.14)$ & $69.67(2.88)$ & 5.31 & $0.003^{*}$ & 26 & $62.83(3.66)$ & $70.50(3.73)$ & -4.90 & $0.004 *$ \\
\hline 34 & $69.33(3.20)$ & $66.67(4.22)$ & 4.34 & $0.007 *$ & 27 & $64.17(4.26)$ & $66.50(5.17)$ & -1.14 & 0.305 \\
\hline 37 & $70.00(2.76)$ & $64.83(3.66)$ & 5.68 & $0.002 *$ & 29 & $64.17(4.62)$ & $68.83(2.04)$ & -4.08 & $0.010^{*}$ \\
\hline 44 & 71. 17(4.54) & $65.17(1.72)$ & 3.72 & $0.014 *$ & 30 & $68.33(3.72)$ & $71.33(3.45)$ & -2.91 & $0.034 *$ \\
\hline 45 & 75. 17(4.07) & 70.17(2.52) & 4. 44 & $0.007 *$ & 31 & $68.00(3.95)$ & $73.00(3.52)$ & -4.84 & $0.005^{*}$ \\
\hline 47 & $71.50(3.33)$ & $66.50(2.59)$ & 3.95 & $0.011^{*}$ & 33 & $71.17(4.26)$ & $76.33(3.01)$ & -4.23 & $0.008^{*}$ \\
\hline 48 & $70.50(2.67)$ & 65. 83(3.06) & 5.53 & $0.003^{*}$ & 35 & $67.00(3.58)$ & $72.83(4.31)$ & -5.41 & $0.003 *$ \\
\hline 49 & 79. 33(1.63) & $76.33(2.33)$ & 2.05 & 0.095 & 36 & $71.83(4.75)$ & $68.33(3.98)$ & 8.17 & $0.000 *$ \\
\hline 52 & 73.17(3.97) & $66.50(5.86)$ & 4.15 & $0.009 *$ & 38 & $66.83(3.65)$ & $71.00(2.37)$ & -4.41 & $0.007 *$ \\
\hline 53 & 73. 33(3.45) & 78. 50(3.45) & -5.68 & $0.002 *$ & 39 & $74.00(2.53)$ & $77.67(2.88)$ & -11.0 & $0.000 *$ \\
\hline
\end{tabular}




\begin{tabular}{lllll}
\hline 54 & $75.83(4.26)$ & $70.00(4.47)$ & 5.26 & $0.003^{*}$ \\
\hline 55 & $69.00(5.55)$ & $73.50(5.09)$ & -6.71 & $0.001^{*}$ \\
\hline 56 & $75.83(6.24)$ & $67.50(4.14)$ & 4.53 & $0.006^{*}$ \\
\hline 57 & $75.17(3.43)$ & $71.00(2.19)$ & 5.26 & $0.003^{*}$ \\
\hline 58 & $67.67(4.08)$ & $72.67(3.33)$ & -5.84 & $0.002^{*}$ \\
\hline 60 & $80.50(2.88)$ & $76.33(2.42)$ & 3.03 & $0.029^{*}$ \\
\hline 61 & $79.00(3.74)$ & $73.83(2.92)$ & 3.27 & $0.022^{*}$ \\
\hline \multicolumn{5}{c}{$\begin{array}{l}\text { Note. } \\
\text { Group of students that have high } \\
\text { accumulated scores in theoretical subjects } \\
\text { Group of students that have high } \\
\text { accumulated scores in practical subjects } \\
\text { The highest scores of both tests }\end{array}$} \\
&
\end{tabular}

\begin{tabular}{ccccc}
\hline 40 & $65.00(3.29)$ & $68.83(2.64)$ & -8.03 & $0.000^{*}$ \\
\hline 41 & $66.00(3.57)$ & $68.00(2.28)$ & -1.55 & 0.182 \\
\hline 42 & $58.00(2.97)$ & $62.50(3.39)$ & -20.1 & $0.000^{*}$ \\
\hline 43 & $75.17(3.97)$ & $80.67(4.27)$ & -2.91 & $0.034^{*}$ \\
\hline 46 & $67.00(2.83)$ & $74.00(4.34)$ & -4.65 & $0.006^{*}$ \\
\hline 50 & $68.67(2.07)$ & $65.00(3.22)$ & 2.86 & $0.035^{*}$ \\
\hline 51 & $58.33(1.97)$ & $60.17(1.17)$ & -2.80 & $0.038^{*}$ \\
\hline 59 & $72.67(3.88)$ & $78.17(4.17)$ & -2.42 & 0.060 \\
\hline 62 & $69.83(3.73)$ & $75.17(4.45)$ & -4.54 & $0.006^{*}$ \\
\hline 63 & $68.17(2.32)$ & $74.33(4.84)$ & -4.07 & $0.010^{*}$ \\
\hline 64 & $69.33(2.34)$ & $72.50(1.87)$ & -2.53 & $0.050^{*}$ \\
\hline 65 & $72.50(4.32)$ & $77.83(3.66)$ & -5.06 & $0.004^{*}$ \\
\hline$* \mathrm{p}<.05$ is the level of significance & & \\
\hline
\end{tabular}

\subsection{A test by making students draw a sketch design}

In Test session 1 (Sketch Design 1), students are given details and scoring criteria and in Test session 2 (Sketch Design 2), students will not be given details and scoring criteria; both tests have a total score of 100. From testing 65 students of the current year industrial design program using both of the tests, the analysis results are as follows:

Comparing the mean scores of two different tests which are not independent, the analysis results found that 59 students performing the test in both sessions show statistically significant differences at the 0.05 level; except for six students at the order 7, 17, 27, 41, 49 and 59 showing no statistically significant differences.

The tests reveal that 25 out of 30 students or $83.33 \%$ of the group of students having high accumulated scores in theoretical subjects have an aptitude in Sketch Design 1, which gives detailed procedures and scoring criteria higher than Sketch Design 2; which gives no details and scoring criteria.

While there are 30 out of 35 students or $85.71 \%$ of the group of students having high accumulated scores in the practical subject that have an aptitude in Sketch Design2; which gives no details and scoring criteria.

In conclusion, the group of students with high accumulated scores in theoretical subjects are found to have an aptitude in Sketch Design 1, given detailed procedures and scoring criteria; while, the group of students that have high accumulated sores in practical subjects found to have an aptitude in Sketch Design 2 given no details and scoring criteria. There are 55 out of 65 students or $84.62 \%$ that met this criterion; the details are shown in Table 5 .
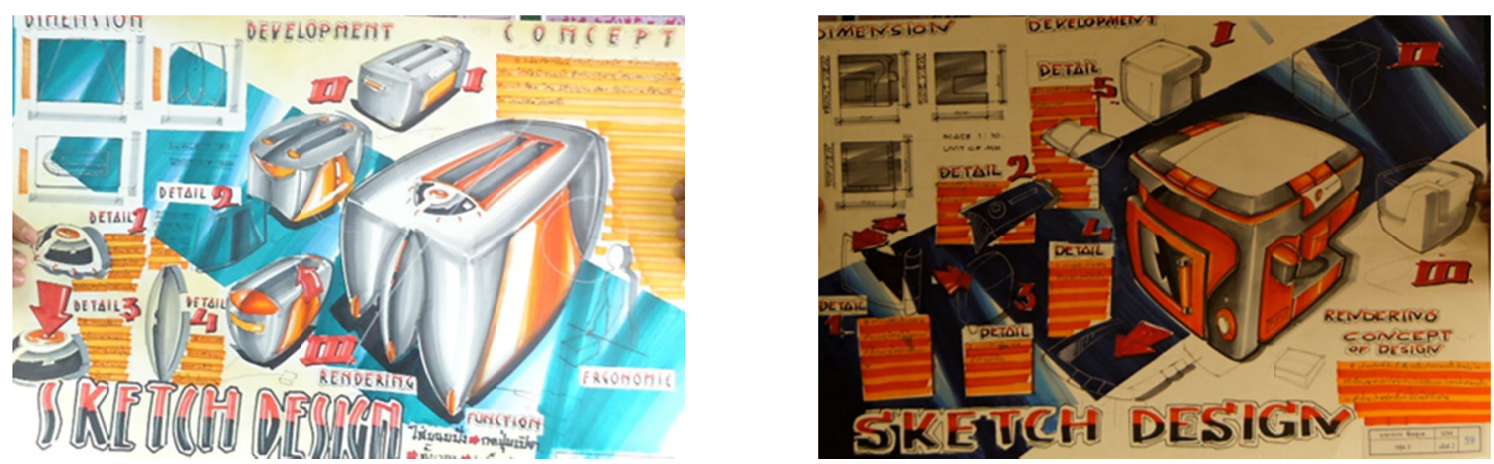

Figure 4. Example of sketch designs from Sketch Design 1 and Sketch Design 2

\subsection{Comparison between the two groups of students and two sketch designs}

Differences were found between mean score, the comparison between two groups of students and two sketch design processes in which the two groups are not independent. The analysis results found that Sketch Design 1, Sketch Design 2 the group of students that have accumulated scores in theoretical subjects and the group of students that have accumulated score in practical subjects have the statistically significant differences at the 0.05 level; the details are shown in table 6.

Table 6. The mean score VS the comparison between the two groups of students and Sketch Design 1 and Sketch Design 2

\begin{tabular}{lcccc}
\hline & $\begin{array}{c}\text { Group of Students with accumulated } \\
\text { scores in theoretical subjects }\end{array}$ & $\begin{array}{c}\text { Group of Students with accumulated } \\
\text { scores in practical subjects }\end{array}$ & \multicolumn{2}{c}{$\begin{array}{c}\text { Independent } \\
\text { Samples Test }\end{array}$} \\
\cline { 2 - 5 } & $M(S D)$ & $M(S D)$ & $\mathrm{t}$ & $p$ \\
\hline Sketch Design 1 & $73.69(4.10)$ & $67.30(4.17)$ & 6.215 & $0.000^{*}$ \\
\hline Sketch Design 2 & $68.92(5.12)$ & $71.47(5.01)$ & -2.029 & $0.047^{*}$ \\
\hline
\end{tabular}




\section{Discussion}

Teaching processes have an impact on design idea communication processes: important elements and guidelines for the systematic designing process; it can also be used as a designing frameworks. Applying the information based on the conceptual ideas helps the designs to achieve the objectives. Each designer would have different design ideas, aptitude and design processes, the researchers found learning subjects and students' aptitude can be divided into two groups which are students that have accumulated scores in theoretical subjects and students that have accumulated scores in practical subjects. The group of students with accumulated scores in theoretical subjects would have an aptitude in the idea sketch design transferring processes that give detailed procedures and scoring criteria because this group of students would have systematical planning and work in detailed sequences. On the other hand, the group of students that have accumulated scores in practical subjects would have aptitude in idea sketch design transferring processes that are not given details and scoring criteria since this group of students like freedom of thinking and can learn from their mistakes and learn from the complicated situations, these students can analyze the stories and scenarios and turn into design ideas.

From these sketch design tests, it is found that although these two tests have different details and processes, they both support design creativity concepts. Also, they have to use the thinking process that derives from the brain, eyes and hands. The difference between these two processes affect learning and teaching industrial design (Sahachaisaeree, 2004). Also, the academic achievement of the students who have different aptitude indicators factor would have an impact on design idea transferring processes and skills in industrial design (Soodsang, 2005). In the present, students have many different conceptual design processes which may due to their former knowledge and access to knowledge in the form of criticism, knowledge synthesis and self-exploration, awareness of the difficulty and complexity of design, as well as the differences in individual which are differences in terms of learning styles, design ability and communication skills (Adi, 2015).

\section{Acknowledgments}

The author would like to thank Assoc. Prof. Dr.NopadonSahachaisaeree and Asst. Prof. Dr.YaninRugwongwan, Faculty of Architecture, King Mongkut's Institute of Technology Ladkrabang, Thailand, for their kind suggestions, guidance, and support to the researcher. I also would like to thank Faculty of Architecture and Design, Rajamangala University of Technology Phra Nakhon, Thailand, for a scholarship to pursue my PhD course work and dissertation.

\section{References}

Adi, F. e. (2015). Conceptualisation as Key Factor in Seizing Design Project in Studio Learning Environment. Journal of ASIAN Behavioural Studies, 5(20), 13-23.

Authority, V. C. (2013). Product Design and Technology. Victoria, Australian: Victorian Curriculum and Assessment Authority.

Kolb, D. (1984). Experiential learning: Experience as. Englewood Cliffs, NJ: Prentice Hall.

Laseau, P. (2001). Graphic thinking for architects and designers. London: Vanostand.

Sahachaisaeree, N. (2004). Sustanable paradigm in interior design. Bangkok: Kasembundit University.

Soodsang, N. (2005). Factors Affecting Achievement level and Industrial Product Design Skills for Undergraduate Students. Industrial Education, 4, 12-20.

Soodsang, N. (2005). Industrial Design Research. Bangkok: Odeon Store.

Zeisel, J. (1981). Inquiry by design: tools for environment-behavior research. Cambridge: Cambridge University

\section{Copyrights}

Copyright for this article is retained by the author(s), with first publication rights granted to the journal.

This is an open-access article distributed under the terms and conditions of the Creative Commons Attribution license (http://creativecommons.org/licenses/by/4.0/). 